\title{
Pengaruh Pendekatan Konstruktivisme Melalui Metode Eksperimen pada Pokok Bahasan Elastisitas Terhadap Kemampuan Penyelesaian Soal Uraian
}

\author{
Fatimah $^{1}$, Juwita ${ }^{2}$ \\ ${ }^{1)}$ Pendidikan Fisika, STKIP Bima \\ Jl. Tendean Kel. Mande Kota Bima-NTB \\ Email : fathmariama@gmail.com
}

\begin{abstract}
ABSTRAK : Penelitian ini bertujuan untuk mengetahui: Pengaruh menggunakan pendekatan konstruktivisme melalui metode eksperimen pada pokok bahasan elastisitas terhadap kemampuan penyelesaian soal uraian pada kelas XI SMAN 3 Kota Bima. Penelitian ini menggunakan pendekatan konstruktivisme melalui metode eksperimen. Populasi penelitian ini yaitu seluruh siswa kelas XI MIA semester I SMA Negeri 3 Kota Bima tahun pelajaran 2018/2019. Teknik pengambilan sampel yang digunakan yaitu cluster random sampling sehingga diperoleh dua kelas, yaitu kelas XI MIA 2 sebagai kelas eksperimen dengan jumlah sampel 25 siswa dan kelas XI MIA 3 sebagai kelas kontrol dengan jumlah sampel 26 orang. Kedua kelas tersebut diasumsikan mempunyai keadaan awal yang sama. Teknik pengumpulan data yang digunakan adalah teknik tes dengan menggunakan soal uraian. Pengujian instrument penelitian menggunakan uji hipotesis dengan menggunakan rumus uji t. Berdasarkan hasil penelitian diperoleh nilai $\mathrm{T}$ hitung $=2.4 \mathrm{I} 6$ sedangkan $\mathrm{T}$ table $=2.000$ yang artinya $\mathrm{T}$ hitung $>\mathrm{T}$ tabel. Jadi dapat disimpulkan bahwa Ho ditolak dan Ha diterima, dalam hal ini menunjukan terdapat pengaruh pendekatan konstruktivisme melalui metode eksperimen terhadap kemampuan penyelesaian soal uraian siswa pada kelas XI SMAN 3 Kota Bima tahun pelajaran 2018/2019.
\end{abstract}

\section{Kata kunci: Konstruktivisme, metode eksperimen, penyelesaian soal uraian}

\section{PENDAHULUAN}

Fisika masih dianggap sebagai mata pelajaran yang sulit oleh sebagian besar siswa, baik di Sekolah Menengah Pertama (SMP) maupun Sekolah Menengah Atas (SMA). Meskipun Fisika mata pelajaran yang dianggap sulit, tetapi materi pelajaran fisika sering ditemukan dalam kehidupan sehari-hari. Artinya, sebagian materi fisika itu ada di lingkungan siswa itu sendiri. Sebagai contohnya yaitu materi elastisitas yang merupakan materi fisika di lingkungan sekitar. Konsep elastisitas menjelaskan benda yang sudah diberi gaya akan mengalami perubahan dan ketika dilepas dapat kembali dalam bentuk semula, contohnya seperti karet dan pegas. Masalahnya sampai dimana kemauan siswa untuk mempelajari lingkungannya sendiri dan sejauh mana kepedulian guru untuk memberikan pemahaman kepada siswa tentang materi pelajaran fisika. Masalah yang sering ditemukan pada siswa adalah kesulitan mereka dalam menyelesaiakan soal uraian, karena dalam penyelesaian soal uraian siswa diajak berpikir mengaitkan antara rumus dengan konsep.

Kurangnya kemampuan siswa dalam menyelesaikan soal uraian dipengaruhi oleh beberapa faktor salah satunya yaitu melalui pendekatan dan metode pembelajaran yang digunakan. Selama ini guru hanya menyampaikan materi dengan metode ceramah dan guru lebih menekankan siswa untuk latihanlatihan soal, sehingga siswa hanya mendengarkan apa yang di sampaikan oleh guru dan mengerjakan apa yang diperintahkan oleh guru. Hal ini kurang meberikan stimulus pada pengetahuan siswa tentang konsep dan rumus fisika sehingga mengakibatkan siswa kurang mampu dalam menyelesaikan soal uraian yang diberikan.

Salah satu pendekatan dan metode pembelajaran yang dapat diterapkan adalah menggunakan pendekatan konstruktivisme dan metode eksperimen. Pendekatan konstruktivisme yang merupakan proses pembelajaran yang menerangkan bagaimana pengetahuan disusun dalam pemikiran pelajar. Pengetahuan dikembangkan secara aktif oleh pelajar itu sendiri dan tidak diterima secara pasif dari orang disekitarnya.

Pembelajaran Konstruktivisme menyatakan bahwa siswa harus menemukan sendiri dan mentransformasikan informasi kompleks, mengecek informasi baru dengan aturan-aturan lama. Teori konstruktivisme memandang perkembangan kognitif sebagai suatu proses dimana anak secara aktif membangun sistem makna dan pemahaman realitas melalui pengalamanpengalaman dan interaksi mereka [I].

Hal ini bermakna bahwa pembelajaran merupakan hasil dari usaha pelajar itu sendiri dan bukan hanya ditransfer dari guru kepada pelajar. Hal tersebut berarti siswa tidak lagi berpegang pada konsep pengajaran dan pembelajaran yang lama, dimana guru hanya menuangkan atau mentransfer ilmu kepada siswa,

Ada beberapa karakteristik pembelajaran dalam model Konstruktivisme antara lain : berpikir kritis, motivasi, idependensi pembelajaran, feadback, dialog, bahasa, penjelasan, bertanya, belajar melalui mengajar, kontekstualisasi, eksperimen, dan pemecahan masalah dalam dunia nyata [2]. Di lihat dari penjelasan di atas, pembelajaran Konstruktivisme sangat cocok disandingkan dengan metode eksperimen. Metode eksperimen adalah cara penyajian pelajaran, di mana siswa melakukan percobaan dengan mengalami sendiri sesuatu yang dipelajari. Dalam proses belajar mengajar, dengan metode eksperimen, siswa diberi kesempatan untuk mengalami sendiri atau melakukan sendiri, mengikuti suatu proses, mengamati suatu obyek, keadaan atau proses sesuatu. Dengan demikian, siswa dituntut untuk mengalami sendiri, mencari kebenaran, atau mencoba mencari suatu hukum atau dalil, dan menarik kesimpulan dari proses yang dialaminya itu [3]

Metode eksperimen ini memberikan kesempatan kepada siswa baik perorangan atau kelompok untuk dilatih melakukan suatu proses atau percobaan. Ini perlu didukung oleh alat-alat praktikum yang memadai, namun bukan berarti keterbatasan ini 
akan menjadi alasan bagi guru untuk menerima kenyataan dengan apa adanya. Melakukan eksperimen bias dilakukan dengan alat dan bahan yang sederhana, mudah didapat sesuai dengan kebutuhan konsep materi yang dibahas seperti konsep elatisitas dimana alat dan bahan bias di temukan dalam kehidupan siswa sehari-hari seperti karet, fir atau spring dan yang sejenisnya

\section{METODE PENELITIAN}

Jenis penelitian yang digunakan adalah Quasi Experimental Design [4]. Desain penelitian ini mempunyai kelas kontrol dan kelas eksperimen. Penelitian ini menggunakan desain nonequivalent kontrol group design. Desain ini melibatkan dua kelompok yaitu kelompok eksperimen dan kelompok kontrol. Dalam desain nonequivalent kontrol group design, kelompok yang satu diberikan perlakuan dan yang lainnya tidak diberi perlakuan, artinya sama seperti biasanya [5]. Dalam penelitian ini kelompok eksperimen diberikan pembelajaran dengan menggunakan pendekatan konstruktivisme melalui metode eksperimen, sedangkan kelompok kontrol diberikan pembelajaran seperti biasanya yaitu dengan model konvensional.

Adapun rancangan penelitian ini seperti pada dibawah ini :

Tabel I. Desain Evaluasi HAsil Belajar Kelas Eksperimen dan Kelas Kontrol

\begin{tabular}{lccc}
\multicolumn{1}{c}{ Kelompok } & Prettest & Perlakuan & Posttest \\
\hline Eksperimen & $\mathrm{O}_{\mathrm{I}}$ & $\mathrm{X}_{\mathrm{I}}$ & $\mathrm{O}_{2}$ \\
Kontrol & $\mathrm{O}_{\mathrm{I}}$ & & $\mathrm{O}_{2}$ \\
\hline
\end{tabular}

Teknik pengambilan sampel dari penelitian ini adalah menggunakan Cluster Random Sampilng. Cluster Random Sampling adalah teknik pengambilan sampel dilakukan secara acak tanpa memperhatikan strata yang ada dalam populasi itu. Teknik Simple Random Sampling tersebut dipilih dua kelas sebagai sampel dalam penelitian ini, yaitu kelas XI MIA-2 sebagai kelas eksperimen dengan jumlah siswa 25 orang dan kelas XI MIA-3 sebagai kelas kontrol dengan jumlah siswa 26 orang. Alasan untuk memilih kelas tersebut karena melihat dari kurangnya antusias siswa dalam proses belajar serta kurangnya pemahaman terhadap materi yang disampaikan oleh guru.

Instrumen penelitian merupakan alat yang digunakan peneliti untuk mengumpulkan data agar pekerjaannya lebih mudah dan hasilnya lebih baik, dalam arti lebih cermat, lengkap dan sistematis sehingga lebih mudah diolah [6]. Kualitas instrumen akan menentukan kualitas data yang terkumpul.

Pada penelitian ini instrumen yang digunakan berupa soal evaluasi. Tes diberikan pada awal pembelajaran (prettest) untuk melihat kemampuan awal siswa kelas eksperimen maupun kelas kontrol dan setelah diberikan perlakuan (posttest) untuk melihat pengaruh dari pembelajaran dengan menggunakan pendekatan konstruktivisme melalui metode eksperimen.

Teknik pengumpulan data yang dilakukan dalam penelitian ini ada dua yaitu dokumentasi dan tes.

\section{Pengujian Instrumen Penelitian}

\section{Validitas}

Validitas adalah suatu ukuran yang menunjukkan tingkat-tingkat kevalidan atau kesahihan suatu instrumen [6]. Untuk validitas butir soal dihitung menggunakan rumus korelasi product moment yaitu :

\section{$r_{X y}=\frac{N \Sigma X Y-(\Sigma X)(\Sigma Y)}{\sqrt{\left[N \Sigma X^{2}-(\Sigma X)^{2}\right]\left[N \Sigma Y^{2}-(\Sigma Y)^{2}\right]}}$}

\section{Reliabilitas}

Untuk uji reliabilitas pilihan ganda dapat dihitung dengan rumus K-R 20. Rumusnya yaitu :

$$
\mathrm{r}_{I I}=\left(\frac{k}{k-1}\right)\left(\frac{S D^{2}-\sum p q}{S D^{2}}\right)
$$

Tabel 2. Kriteria Indeks Reliabilitas

\begin{tabular}{ll} 
Koofisien korelasi & Kriteria \\
\hline $0,00-020$ & Sangat rendah \\
$0,20-0,40$ & Rendah \\
$0,40-0,60$ & Cukup \\
$0,60-0,80$ & Tinggi \\
$0,80-1,00$ & Sangat tinggi \\
\hline
\end{tabular}

\section{Analisis Data}

Data penelitian yang diperoleh kemudian diolah dan dianalisis agar dapat dipahami bukan hanya peneliti, maka data yang diperoleh harus diuraikan melalui analisis data.

\section{Uji Prasyarat Analisis}

I. Uji Normalitas

Uji normalitas digunakan untuk mengetahui data yang dianalisis berdistribusi normal atau tidak. Uji statistika yang digunakan adalah uji chi-kuadrat dengan rumus :

$$
x^{2}=\sum_{i=1}^{k} \frac{f o-f e)^{2}}{f e}
$$

Adapun kriteria pengujian yaitu: Jika nilai

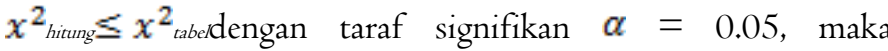
diasumsikan data berasal dari populasi yang berdistribusi normal. Sebaliknya nilai $x^{2}$ hitung $\geq x^{2}$ tabel dengantarafsignifikan $\alpha=0.05$, maka diasumsikan data berasal dari populasi yang tidak terdistribusi normal.

2. Uji Homogenitas

Uji homogenitas merupakan pengujian dua rata-rata memiliki distribusi tertentu. Uji homogenitas digunakan untuk menguji apakah kedua data pada kelas eksperimen dan kelas kontrol tersebut homogen atau tidak. Uji homogenitas dilakukan dengan menggunakan dua varian atau uji Fisher. Langkah-langkahnya sebagai berikut:

$$
\begin{gathered}
\mathrm{F}=\frac{S_{1}^{2}}{S_{2}^{2}} \text { dimana, } \\
S_{1}=\frac{n \sum X^{2}-\left(\sum X\right)^{2}}{n(n-1)} \text { dan } S_{2}=\frac{n \sum X^{2}-\left(\sum X\right)^{2}}{n(n-1)}
\end{gathered}
$$

\section{Uji hipotesis}

Jika sampel berdistribusi normal dan homogen, maka dilakukan uji parametrik dengan uji hipotesis statistik menggunakan rumus uji t dengan taraf signifikan $\alpha=0,05$ atau 5\% (Sugiyono, 2012). Adapun rumus uji t sebagai berikut : 


$$
\begin{gathered}
t_{\text {hitung }}=\frac{\bar{X} 1-\bar{X} 2}{S^{2} \sqrt{\frac{1}{n 1}+\frac{1}{n 2}}} \\
\text { Dengan } S^{2}=\frac{\left(n_{1}-1\right) S_{1}^{2}+\left(n_{2}-1\right) S_{1}^{2}}{n_{1}+n_{2}-2}
\end{gathered}
$$

\section{HASIL DAN PEMBAHASAN}

Dari hasil perhitungan uji validitas diperoleh soal yang valid sebanyak 5 nomor dan tidak valid sebanyak 5 nomor, sehingga yang tidak valid dibuang.Adapun hasil perhitungan prettest dan posttest pada kelas kontrol dan kelas eksperimen dapat dilihat pada tabel sebagai berikut :

Tabel 3. Hasil Analisis Deskriptif Skor Prettestdan Posttest Kemampuan Penyelesaian Soal Uraian Siswa Pada Pokok Bahasan Elastisitas.

\begin{tabular}{lllll}
\multirow{2}{*}{ Statistik } & \multicolumn{2}{l}{ Kelas Eksperimen } & \multicolumn{2}{l}{ Kelas Kontrol } \\
\cline { 2 - 5 } & Pret test & Post test & prettest & Post test \\
\hline Skor maks. & 40 & 96 & 30 & 82 \\
Skor min. & I5 & 70 & I0 & 35 \\
Jumlah & $6 \mathrm{I} 5$ & 2046 & 460 & $\mathrm{I} 524$ \\
Skor rerata & 24.52 & $8 \mathrm{I}, 84$ & 17.69 & $58.6 \mathrm{I}$ \\
SD & 5.730 & 8.668 & 4,945 & 15.897 \\
Rentang skor & 25 & 26 & 20 & 50 \\
Varian & 32.843 & 75.14 & $24,46 \mathrm{I}$ & 252.897 \\
\hline
\end{tabular}

Sebelum diberi perlakuan (pretest) jumlah nilai prettest pada kelas kontrol diperoleh sebesar 460, nilai rataratadiperolehsebesar 17.69 , skor maksimum 30, skor minimum I0 dengan standar deviasi 4.945, nilai varians sebesar 24.46 I dan dengan rentang skor sebesar 20. Sedangkan nilai prettest pada kelas eksperimen diperoleh jumlah 6I5, nilai rata-rata diperoleh sebesar 24.52, skor maksimum 40, skor minimum I5 dengan standar deviasi sebesar 5.730, nilai varians 32.843 dan dengan rentang skor 25 .

Setelah diberi perlakuan (posttest) jumlah nilai posttest pada kelas kontrol diperoleh sebesar I524, nilai rata-rata diperoleh sebesar sebesar 58.6I, skor maksimum 85, skor minimum 35 dengan standar deviasi sebesar 15.897, nilai varians sebesar 252.72 dan rentang skor sebesar 50. Sedangkan jumlah nilai pada kelas eksperimen diperoleh sbesar 2046, nilai rata-rata diperoleh sebesar. 81.84, skor maksimum 96, skor minimum 70 dengan nilai standar deviasi sebesar 8.668, nilai varians 75.14 dan rentang skor sebesar 26.

Berdasarkan tabel di atas dapat disimpulkan bahwa dengan pendekatan konstruktivisme melalui metode eksperimen pada siswa kelas eksperimen diperoleh skor kemampuan penyelesaian soal uraian lebih tinggi dari pada siswa kelas kontrol yang diajar menggunakan pembelajaran secara konvensional.

\section{Uji Normalitas}

Uji normalitas ini dilakukan untuk mengetahui apakah yang diperoleh berdistribusi normal atau tidak berdistribusi normal. Hasil uji normalitas akan berpengaruh terhadap uji hipotesis yang digunakan, statistik parametrik dan non parametrik. Pengelolaan data untuk uji normalitas menggunakan uji chi-kuadrat dengantaraf signifikasi $\alpha$ adalah 0.05 .

Tabel 4. Hasil Analisis Uji Normalitas Pada Kelas kontrol dan Kelas Eksperimen

\begin{tabular}{cccc} 
Kelas & Nilai X $^{2}$ hitung & Nilai X $_{\text {tabel }}$ & Status \\
\hline Kelas control & 2.89 & 38.885 & $\mathrm{X}_{\text {hitung }}^{2}<\mathrm{X}_{\text {tabel }}^{2}$ \\
$\begin{array}{c}\text { Kelas } \\
\text { Eksperimen }\end{array}$ & 29.42 & 37.652 & $X^{2}{ }_{\text {hitung }}<X_{\text {tabel }}^{2}$ \\
\hline
\end{tabular}

Berdasarkan tabel hasil analisis di atas, diperoleh nilai signifikansi kemampuan penyelesaian soal uraian dari kelas kontrol melalui pembelajaran secara konvensional adalah $X_{\text {hitung }}<X_{\text {tabelatau }}^{2} 2.89<38.885$, sehingga hasil uji normalitas kelas kontrol berdistribusi normal. Sedangkan pada kelas eksperimen adalah $X_{\text {hitung }}^{2}<X^{2}$ tabel atau $29.42<37.652$, sehingga hasiluji normalitas kelas eksperimen berdistribusi normal. Berdasarkan hal tersebut, maka hasil pengujian untuk kedua kelas tersebut berasal dari populasi yang berdistribusi normal

\section{Uji Homogenitas}

Uji homogenitas bertujuan untuk mengetahui apakah data dalam penelitian ini memiliki varians yang sama atau homogen. Adapun hasil uji homogenitas dengan taraf nyata 0.05. Dapat dilihat pada tabel sebagai berikut :

Tabel 5. Hasil Uji Homogenitas Kemampuan Penyelesaian Soal Uraian

\section{Kemampuan Penyelsaian Soal Uraian Kelas

\begin{tabular}{|c|c|c|}
\hline Kelas & $F_{\text {hitung }}$ dan $F_{\text {tabel }}$ & Status \\
\hline Kelas & \multirow[b]{3}{*}{$\begin{aligned} F_{\text {hitung }} & =0.0886 \\
F_{\text {tabel }} & =3.606\end{aligned}$} & \multirow{3}{*}{$\begin{array}{c}F_{\text {hitung }}<\mathrm{F}_{\text {tabel }} \\
\mathrm{H}_{\mathrm{o}}=\text { data } \\
\text { memiliki } \\
\text { varian } \\
\text { homogeny }\end{array}$} \\
\hline eksperimen & & \\
\hline Kelas kontrol & & \\
\hline
\end{tabular} kontrol dan Eksperimen}

Berdasarkan uji homogenitas pada tabel di atas, diperoleh hasil uji homogenitasnya adalah $\mathrm{F}_{\text {hitung }}<\mathrm{F}_{\text {tabel }}$ atau $\mathrm{Ho}=$ data memiliki varian homogen yang artinya data diterima. Dapat disimpulkan bahwa kedua data pada kelas kontrol dan kelas eksperimen memiliki data yang berdistribusi homogeny.

\section{Uji Hipotesis}

Setelah dilakukan perhitungan uji normalitas dan uji homogenitas, maka selanjutnya dilakukan analisis menguji kebenaran hipotesis. Pengujian hipotesis dengan uji dua pihak dengan menggunakan uji t padataraf kepercayaan $\alpha=0.05$. Adapun tabel hipotesis sebagai berikut :

Tabel 7. Hasil Uji Hipotesis Kemampuan Penyelesaian Soal Uraian

Kemampuan Penyelsaian Soal Uraian Kelas kontrol dan Eksperimen

\begin{tabular}{ccc}
\hline Kelas & $\mathrm{T}_{\text {hitung }}$ dan $\mathrm{T}_{\text {tabel }}$ & status \\
\hline $\begin{array}{c}\text { Kelas } \\
\text { eksperimen }\end{array}$ & $\mathrm{T}_{\text {hitung }}=2.4 \mathrm{I} 6$ & $\mathrm{~T}_{\text {hitung }}<\mathrm{F}_{\text {tabel }}$ \\
\cline { 1 - 2 } Kelas kontrol & $\mathrm{T}_{\text {tabel }}=2.000$ & $\mathrm{H}_{\mathrm{a}}=\begin{array}{c}\text { terdapat pengaruh } \\
\text { terdat }\end{array}$
\end{tabular}

Dari hasil perhitungan diperoleh bahwa nilai thitung sebesar 2.4I6 dan nilai tabel sebesar 2.000 atau thitung $>_{\text {tabel, }}$ maka dalam hal ini Ho ditolak dan $\mathrm{H}_{\mathrm{a}}$ diterima. Dengan demikian dapat 
disimpulkan bahwa dalam hal ini terdapat pengaruh menggunakan pendekatan konstruktivisme melalui metode eksperimen.

Dengan demikian, dapat dikemukakan bahwa pendekatan konstruktivisme merupakan salah satu alternatif dalam pembelajaran yang dapat digunakan untuk meningkatkan kemampuan penyelesaian soal uraianpada pokok bahasan elastisitas pada kelas XI SMA Negeri 3 Kota Bima.

\section{KESIMPULAN}

Berdasarkan hasil analisis dan pembahasan maka dapat dikemukakan bahwa kemampuanpenyelesaian soal pada kelas eksperimen yang diajarkan dengan pendekatan konstruktivisme melalui metode eksperimen lebih tinggi dibandingkan dengan nilai pada kelas kontrol yang diajarkan secara konvesional. Terdapat perbedaankemampuan penyelesaian soal uraian antara yang diajar menggunakan pendekatan konstruktivisme dengan yang diajar secara konvensional pada poko bahasan elastisitaspada kelas XI SMA Negeri 3 Kota Bima tahun pelajaran 2018/2019.

\section{DAFTAR PUSTAKA}

[1] Trianto. 20I I. Mendesain Model Pembelajaran InovatifProgresif. Jakarta : Prenada Media Group.

[2] Wardoyo, Sigit Mangun. 2013. Pembelajaran Konstruktivisme. Bandung: Alfabeta

[3] Djamarah Syaiful Bahri. 2002. Strategi Belajar Mengajar. Jakarta : Rineka Cipta

[4] Sugiyono, 20I3. Statistik Nonparametris Untuk Penelitian. Penerbit Alfabeta : Bandung

[5] Sugiyono, 2012. Statistik Nonparametris Untuk Penelitian. Penerbit Alfabeta : Bandung

[6] Arikunto, S. 20I0. Dasar-dasar Evaluasi Pendidikan edisi 2. Jakarta: Bumi Aksara.

[7] Sudjana, N. (2002). Metode Statistik Edisi ke-6. Bandung: Tarsito 